\title{
Effect of crude extracts and essential oils of aromatic plants against Sclerotinia sclerotiorum in potato fields
}

\author{
Efecto de extractos crudos y aceites esenciales de plantas \\ aromáticas contra Sclerotinia sclerotiorum en campos de papa
}

Seyedmohammadreza Ojaghian ${ }^{1,2}$, Ali Davoudi ${ }^{3}$

\begin{abstract}
This study was carried out to determine inhibitory effect of crude extracts and essential oils (OE) of aromatic plants against Sclerotinia sclerotiorum in potato fields in Bahar and Lalehjin, Iran during cropping seasons of 2015 and 2016. The results showed that crude extracts of cinnamon and ginger at concentrations $5 \mathrm{~g} / \mathrm{l}$ as well as essential oils of coriander, lavender, thyme, savory and eucalyptus at concentration $50 \mu \mathrm{l} / \mathrm{ml}$ had potential to significantly reduce incidence of potato white mold. This is the first study about inhibitory effect of crude extracts and essential oils of aromatic plants against potato white mold under field condition.

Keywords: Bahar, Cinnamon, ginger, iprodione, Lalehjin; savory.
\end{abstract}

\section{RESUMEN}

Este estudio se realizó para determinar el efecto inhibitorio de los extractos crudos y aceites esenciales de plantas aromáticas (AE) contra Sclerotinia sclerotiorum en los campos de papa en Bahar y Lalehjin, Irán, durante las temporadas de cultivo de 2015 y 2016. Los resultados mostraron que los extractos crudos de canela y jengibre en concentraciones 5 g/l, así como los aceites esenciales de cilantro, tomillo, lavanda, ajedrea y eucalipto a una concentración de $50 \mu \mathrm{l} / \mathrm{ml}$ tenían el potencial de reducir significativamente la incidencia de moho blanco de papa. Este es el primer estudio sobre el efecto inhibitorio de los extractos crudos y aceites esenciales de plantas aromáticas contra el moho blanco de la papa en condiciones de campo.

Palabras clave: Bahar, canela, jenjibre, iprodiona, Lalehjin, ajedrea.

\section{Introduction}

Sclerotinia sclerotiorum (Lib.) de Bary is an ascomycetous fungus which attacks a large number of higher plants in the world (Purdy, 1979). The pathogen causes a destructive disease on potato plants which is called white mold or stem rot. Potato white mold occurs in many potato-growing regions of Hamedan province, Iran especially in Bahar and Lalehjin counties. The disease is usually observed in moist conditions often occurred in the fields irrigated with overhead systems. Due to considerable crop damage, lack of highly resistant cultivars and difficulty of managing sclerotinia diseases, a large number of researches are yearly focused on S. sclerotiorum. Because initial symptoms of white mold are observed on the lower parts of plants, the disease is not usually recognized by potato growers until plant is wilted at the last weeks of growing season. Because potato tuber is mostly formed at the ending weeks of cropping season and no control method is conducted against potato white mold, significant yearly yield loss is resulted due to the disease (Ojaghian, 2011). The pathogen is a soilborne fungus which overwinters as long-lasting sclerotia in soil. The sclerotia play a principal role in disease cycle and can be viable in soil for more than eight years (Adams and Ayers, 1979). After

\footnotetext{
1 Department for Management of Science and Technology Development, Ton Duc Thang University. Ho Chi Minh City, Vietnam.

2 Smart Agriculture Research and Application Team, Ton Duc Thang University, Ho Chi Minh City, Vietnam

3 Department of Plant Protection, College of Agriculture. Azad University of Tabriz; Iran.

* Corresponding authors: Seyedmohammadreza.Ojaghian@tdtu.edu.vn
}

Fecha de Recepción: 17 de Diciembre, 2019.

Fecha de Aceptación: 10 Enero, 2020. 
carpogenic germination and apothecia formation under favorite condition, ascospores are produced which are incapable of direct infection of green leaves and stem tissues of potato but they colonize flowers and other senescing tissues using them as energy sources to infect green tissues (Atallah and Johnson, 2004). The airborne ascospores are deposited on potato blossoms attached to the canopy. Infested flowers fall on stems and the ground, and the stems or leaves contacting the colonized flowers are infected with the pathogen. The flowers and other senescing tissues colonized by ascospores were found to cause the majority of observed lesions. Therefore, chemical control against sclerotinia diseases is usually carried out at the stage of flowering. It was reported that removal of the flowers before falling markedly reduced the disease incidence (Johnson and Atallah, 2006; Atallah and Johnson, 2004). Tuber infections are rare, but have been observed. This disease has caused substantial yield loss up to $80 \%$ since recent years in Hamedan, Iran (Ojaghian, 2011).

Although some biocontrol agents have been effective against the disease (Ojaghian, 2010, 2011), the major control method used by potato growers against white mold is application of fungicides mainly iprodione and dichloran (Ojaghian et al., 2015) which has caused a progressive pollution of underwaters (Data not published). Furthermore, fungicide resistance against Sclerotinia spp. has been reported due to continuous application of benzimidazole fungicides (e.g. carbendazim) and dicarboximide fungicides (e.g. iprodione) (Zhang et al., 2003; Jo et al. 2006). Therefore, alternative methods are being searched in order to decrease chemicals application in potato fields of Hamedan province.

According to numerous studies, aromatic plants produce different bioactive substances which have considerable antimicrobial potentials (Castillo et al., 2010).

Previous studies have shown that crude extracts and essential oils of some medicinal plants such as cinnamon and rosemary were able to reduce severity of carrot rot caused by S. sclerotiorum (Ojaghian et al., 2014, 2019). Furthermore E-cinnamaldehyde, as the major component of cinnamon, decreased severity of potato white mold under greenhouse condition (Ojaghian et al., 2015). This study was conducted to evaluate inhibitory effects of crude extracts and essential oils (EO) of aromatic plants against $S$. sclerotiorum in potato fields.

\section{Materials and Methods}

Dried rhizomes of ginger (Zingiber officinale), bark of cinnamon (Cinnamomum cassia), leaves of neem (Azadirachta indica) and leaves of rosemary (Rosmarinus officinalis) were purchased from Huisong pharmaceuticals (Hangzhou, China). In order to carry out extraction, pulverized plant materials $(500 \mathrm{~g})$ were added to $2.5 \mathrm{~L}$ ethanol $(95 \%)$ in flasks. The flasks were kept in an unltrasonic cleaner (Kunshan-500B) for one min to boost solubility and remained in laboratory condition for $20 \mathrm{~h}$. After filtering through Whatman paper $\left(\mathrm{N}^{\mathrm{o}} 1\right)$, the ethanol was evaporated using a rotary evaporator. The crude extracts were kept in glass bottles at $5{ }^{\circ} \mathrm{C}$ until used. The obtained yields of cinnamon, rosemary, ginger and neem extracts were approximately 6.2, 5.9, 5.7 and $6.9 \%$, respectively.

EOs of coriander (Coriandrum sativum), lavender (Lavandula angustifolia), geranium (Pelargonium graveolens), thyme (Thymus vulgaris), savory (Satureja hortensis) and eucalyptus (Eucalyptus globules) were bought from Frey + Lau GmbH, Henstedt-Ulzburg, Germany. The order numbers of above mentioned EOs were P0112145, P0123527, P0114231, P0123774, P0118884 and P0115610, respectively.

Because EOs are not water soluble, ethanol $(95 \%)$ was used as a non-toxic solvent. When it was necessary to be solved in sterile distilled water (SDW), the EO was first solved in ethanol at concentration of $300 \mu \mathrm{l} / \mathrm{ml}$ ethanol.

Field trials were conducted over two years in two naturally highly infested potato fields located at Bahar and Lalehjin, two counties in Hamedan province, during the cropping seasons of 2015 and 2016. The Bahar and Lalehjin fields had been under potato cultivation for five years, and contained clay loam (pH 6.3) and sandy clay loam (pH 6.4) soils, respectively. Field tests were arranged in a randomized complete block design in both years and there were three replications for each treatment. The treatments included: T1-T4: the crude extracts of cinnamon, ginger, rosemary and neem dissolved in sterile distilled water (SDW) at concentration $2 \mathrm{~g} / \mathrm{l}$, T5-T10: essential oils of six medicinal plants including coriander, lavender, geranium, thyme, savory and eucalyptus at concentration $20 \mu \mathrm{lEO} /$ ml SDW, T11-T14: the crude extracts of cinnamon, ginger, rosemary and neem dissolved in sterile distilled water (SDW) at concentration $5 \mathrm{~g} / \mathrm{l}$, 
T15-T20: essential oils of six medicinal plants including coriander, lavender, geranium, thyme, savory and eucalyptus at concentration $50 \mu \mathrm{EO} /$ $\mathrm{ml}$ SDW, T21: fungicide iprodione (Rovral WP, $50 \%$ a.i.; maximum advised application rate 500 $\mathrm{g} \mathrm{ha}^{-1}$, Bayer Ltd., Philadelphia, USA) sprayed at 100\% the advised rate, T22: SDW, T23: ethanol, T24: no treatment.

The potato tubers were sown at 4.8 ton/ ha at a row spacing of $35-40 \mathrm{~cm}$. Urea $(400 \mathrm{~g})$, superphosphate $(600 \mathrm{~g})$ and potassium chloride $(250 \mathrm{~g})$ were cultivated into the soil of each treatment prior to planting tubers. Individual plot sizes were $4.5 \times 5 \mathrm{~m}$ in 2015 and $4 \times 5 \mathrm{~m}$ in 2016 , and one-meter wide borders were maintained unplanted between each replicate plot. The above mentioned treatments were sprayed twice on plants when approximately $20-30$ and $70-80 \%$ of the potato plants were flowering. In both years plots were irrigated with a sprinkler system as needed and weeds were removed by hand.

Potato plants were rated for incidence of white mold (Ojaghian, 2011) during harvesting (late September). Disease incidence was determined as the percent of plants in each plot infected by the pathogen. The percentage of infected plants was measured using the formula $P I=100-(N \times 100 / C)$, where: $P I=$ percentage of infected plants, $N=$ the number of infected plants in treatment and $C=$ the number of infected plants in control. Moreover, the percent of dead plants (as a part of infected plants) was calculated using the formula: $P D=100-(N \times 100 / C)$, where: $P D=$ percentage of dead plants, $N=$ the number of dead plants in treatment and $C=$ the number of dead plants in control. The means of treatments recorded in percent were converted in $\mathrm{Sin}^{-1}$ percentage transformation. Using SAS software, the effects of different treatments were determined by ANOVA (Gomez and Gomez, 1984).

\section{Results and Discussions}

The results showed that crude extracts and essential oils were able to significantly $(P<0.05)$ reduce incidence of potato white mold (Table 1). Based on the results, a positive relation was observed between inhibitory activity against the disease incidence and crude extracts/EOs concentration.

In 2015 (Bahar), the lowest percentage of infected plants was observed in T18, T19 and $\mathrm{T} 21$. The next treatments in order of efficacy were
T11-12, T15-16 and T20 with statistically similar performance. In addition, the best effect against the percentage of dead plants was found to be in T19 and T21 followed by T11-12, T15-16, T18 and T20 with statistically similar results (Table 1).

In 2015 (Lalehjin), the highest effect against the infected plants was observed in T19-21 and no inhibitory effect was observed in T3-7, T13 and T17 compared with controls (Table 1).

In 2016 (Bahar), the treatments T20-21 showed the best efficacy against the disease followed by T11-12, T15-16 and T18-19 with statistically similar results. However the minimum percentage of dead plants was observed in T21 followed by T11-12, T15-16 and T18-19-20 which were statistically at par with each other (Table 1).

In 2016 (Lalehjin), the highest inhibitory effect against the infected plant percentage was found to be in T19 and T21 followed by T11-12, T15-16, T18 and T20 with statistically similar performance. Moreover the lowest number of dead plants was observed in T21 followed by T11-12, T15-16 and T18-20 with statistically at par results (Table 1).

This study showed that crude extracts of cinnamon and ginger at concentrations $5 \mathrm{~g} / \mathrm{l}$ as well as essential oils of coriander, lavender thyme, savory and eucalyptus at concentration $50 \mu \mathrm{EO} / \mathrm{ml}$ SDW had potential to significantly reduce incidence of potato white mold. In addition spraying essential oil of savory at concentration $50 \mu \mathrm{EO} / \mathrm{ml} \mathrm{SDW}$ was as effective as fungicide application in Bahar and Lalehjin during 2015.

The previous studies have shown that the applications of biocontrol agents such as Trichoderma spp., Talaromyces flavus (Ojaghian, 2011) and Coniothyrium minitans (Ojaghian, 2010) have potential to markedly reduce the disease incidence of potato stem rot. In addition, biofumigation caused by Brassica crops was able to decrease incidence of the disease in potato fields of Hamedan (Ojaghian et al., 2012).

In this study, the disease incidence (and not disease severity) of potato stem rot was evaluated. Depending on the microclimate situations, infection of lower parts of the plants can cause just bleach (Figure $1 \mathrm{~A}$ ), or this infection can develop to die the whole plants (Figure $1 \mathrm{~B}$ ). A number of dead plants (as a proportion of infected plants) were always observed in infected fields. Thus, both infected and dead plants were considered in this research. This study was conducted in 
Table 1. Inhibitory efficacy of crude extracts and essential oils of medicinal plants against incidence of S. sclerotiorum in potato fields of Hamedan, Iran during growing seasons of 2015-2016.

\begin{tabular}{|c|c|c|c|c|c|c|c|c|}
\hline \multicolumn{9}{|c|}{ Disease incidence $(\%)^{*}$} \\
\hline & \multicolumn{4}{|c|}{2015} & \multicolumn{4}{|c|}{2016} \\
\hline & \multicolumn{2}{|c|}{ Bahar } & \multicolumn{2}{|c|}{ Lalehjin } & \multicolumn{2}{|c|}{ Bahar } & \multicolumn{2}{|c|}{ Lalehjin } \\
\hline Treatments & $\begin{array}{l}\text { Infected } \\
\text { plants }\end{array}$ & $\begin{array}{l}\text { Dead } \\
\text { plants }\end{array}$ & $\begin{array}{l}\text { Infected } \\
\text { plants }\end{array}$ & $\begin{array}{l}\text { Dead } \\
\text { plants }\end{array}$ & $\begin{array}{l}\text { Infected } \\
\text { plants }\end{array}$ & $\begin{array}{l}\text { Dead } \\
\text { plants }\end{array}$ & $\begin{array}{l}\text { Infected } \\
\text { plants }\end{array}$ & $\begin{array}{l}\text { Dead } \\
\text { plants }\end{array}$ \\
\hline $\mathrm{T} 1$ & $60.5 \pm 18.2^{b}$ & $30.3 \pm 6.8^{\mathrm{b}}$ & $55.8 \pm 14.2^{\mathrm{b}}$ & $25.4 \pm 5.8^{b}$ & $51.9 \pm 14.9^{b}$ & $41.5 \pm 8.4^{b}$ & $51.3 \pm 14.6^{\mathrm{b}}$ & $33.8 \pm 5.7^{\mathrm{b}}$ \\
\hline $\mathrm{T} 2$ & $57.1 \pm 15.3^{b}$ & $20.8 \pm 4.2^{\mathrm{bc}}$ & $52.1 \pm 10.7^{\mathrm{b}}$ & $24.9 \pm 6.7^{b}$ & $49.2 \pm 6.9^{b}$ & $44.1 \pm 10.5^{b}$ & $53.7 \pm 18.2^{b}$ & $30.5 \pm 6.9^{b}$ \\
\hline $\mathrm{T} 3$ & $82.7 \pm 10.8^{\mathrm{a}}$ & $48.2 \pm 12.6^{\mathrm{a}}$ & $76.3 \pm 16.3^{\mathrm{a}}$ & $50.3 \pm 10.2^{\mathrm{a}}$ & $76.1 \pm 12.3^{\mathrm{a}}$ & $58.3 \pm 17.6^{\mathrm{a}}$ & $80.4 \pm 12.7^{\mathrm{a}}$ & $49.1 \pm 8.4^{\mathrm{a}}$ \\
\hline $\mathrm{T} 4$ & $81.5 \pm 19.4^{a}$ & $46.2 \pm 9.4^{\mathrm{a}}$ & $78.5 \pm 14.1^{\mathrm{a}}$ & $52.5 \pm 13.9^{\mathrm{a}}$ & $73.8 \pm 9.1^{\mathrm{a}}$ & $54.1 \pm 8.2^{\mathrm{a}}$ & $78.5 \pm 14.1^{\mathrm{a}}$ & $50.2 \pm 7.1^{\mathrm{a}}$ \\
\hline T5 & $71.3 \pm 18.8^{\mathrm{ab}}$ & $51.4 \pm 13.9^{\mathrm{a}}$ & $80.3 \pm 9.7^{a}$ & $38.8 \pm 17.1^{\mathrm{ab}}$ & $69.9 \pm 18.1^{\mathrm{a}}$ & $49.6 \pm 14.3^{\mathrm{ab}}$ & $69.3 \pm 20.8^{\mathrm{ab}}$ & $42.5 \pm 10.6^{\mathrm{ab}}$ \\
\hline T6 & $72.6 \pm 14.7^{\mathrm{ab}}$ & $49.7 \pm 15.2^{\mathrm{a}}$ & $77.2 \pm 13.9^{\mathrm{a}}$ & $36.9 \pm 14.6^{\mathrm{ab}}$ & $74.8 \pm 13.4^{\mathrm{a}}$ & $58.1 \pm 10.2^{\mathrm{a}}$ & $67.6 \pm 15.2^{\mathrm{ab}}$ & $52.1 \pm 6.7^{\mathrm{a}}$ \\
\hline $\mathrm{T} 7$ & $83.4 \pm 12.4^{\mathrm{a}}$ & $45.9 \pm 7.2^{\mathrm{a}}$ & $75.9 \pm 12.1^{\mathrm{a}}$ & $49.8 \pm 10.1^{\mathrm{a}}$ & $71.9 \pm 16.3^{\mathrm{a}}$ & $59.2 \pm 17.6^{\mathrm{a}}$ & $77.4 \pm 18.3^{\mathrm{a}}$ & $50.2 \pm 12.4^{\mathrm{a}}$ \\
\hline $\mathrm{T} 8$ & $65.3 \pm 17.5^{b}$ & $30.4 \pm 7.9^{b}$ & $53.8 \pm 17.1^{\mathrm{b}}$ & $40.3 \pm 9.7^{\mathrm{ab}}$ & $53.8 \pm 9.5^{b}$ & $39.4 \pm 8.3^{b}$ & $57.2 \pm 8.9^{b}$ & $28.2 \pm 5.3^{b}$ \\
\hline T9 & $61.9 \pm 7.2^{b}$ & $33.8 \pm 6.4^{\mathrm{b}}$ & $56.7 \pm 18.2^{b}$ & $21.2 \pm 8.2^{\mathrm{b}}$ & $61.3 \pm 14.7^{\mathrm{ab}}$ & $42.7 \pm 5.2^{b}$ & $56.5 \pm 12.3^{b}$ & $30.1 \pm 8.6^{b}$ \\
\hline $\mathrm{T} 10$ & $59.1 \pm 9.6^{b}$ & $31.9 \pm 9.5^{b}$ & $54.8 \pm 10.4^{b}$ & $25.8 \pm 6.5^{b}$ & $65.8 \pm 16.3^{\mathrm{ab}}$ & $44.2 \pm 7.8^{b}$ & $55.7 \pm 15.8^{\mathrm{b}}$ & $29.7 \pm 5.8^{b}$ \\
\hline $\mathrm{T} 11$ & $29.7 \pm 5.5^{\mathrm{c}}$ & $12.1 \pm 4.5^{\mathrm{c}}$ & $22.1 \pm 5.8^{c}$ & $10.6 \pm 2.7^{c}$ & $26.1 \pm 7.4^{c}$ & $12.6 \pm 3.5^{\mathrm{c}}$ & $27.8 \pm 3.9^{c}$ & $14.1 \pm 3.2^{\mathrm{c}}$ \\
\hline $\mathrm{T} 12$ & $32.4 \pm 10.7^{c}$ & $14.2 \pm 6.3^{c}$ & $26.3 \pm 9.2^{\mathrm{c}}$ & $12.5 \pm 4.1^{\mathrm{c}}$ & $23.7 \pm 6.5^{\mathrm{c}}$ & $11.8 \pm 5.2^{\mathrm{c}}$ & $24.2 \pm 7.1^{\mathrm{c}}$ & $12.9 \pm 5.8^{\mathrm{c}}$ \\
\hline $\mathrm{T} 13$ & $80.1 \pm 20.9^{a}$ & $50.5 \pm 16.1^{\mathrm{a}}$ & $76.8 \pm 18.9^{a}$ & $51.4 \pm 5.6^{\mathrm{a}}$ & $72.8 \pm 16.9^{a}$ & $54.1 \pm 12.8^{\mathrm{a}}$ & $79.1 \pm 23.6^{\mathrm{a}}$ & $47.3 \pm 9.1^{\mathrm{a}}$ \\
\hline $\mathrm{T} 14$ & $58.9 \pm 17.1^{\mathrm{b}}$ & $29.2 \pm 8.1^{b}$ & $51.2 \pm 8.7^{b}$ & $22.3 \pm 4.8^{b}$ & $45.7 \pm 3.5^{b}$ & $42.2 \pm 3.6^{b}$ & $55.2 \pm 10.8^{\mathrm{b}}$ & $32.4 \pm 6.5^{b}$ \\
\hline $\mathrm{T} 15$ & $33.6 \pm 9.2^{\mathrm{c}}$ & $11.8 \pm 4.6^{c}$ & $22.4 \pm 4.3^{\mathrm{c}}$ & $13.7 \pm 2.8^{\mathrm{c}}$ & $22.8 \pm 4.6^{c}$ & $13.7 \pm 5.2^{\mathrm{c}}$ & $25.1 \pm 4.7^{c}$ & $15.6 \pm 7.8^{c}$ \\
\hline $\mathrm{T} 16$ & $30.8 \pm 7.1^{\mathrm{c}}$ & $13.8 \pm 3.7^{\mathrm{c}}$ & $24.1 \pm 5.5^{\mathrm{c}}$ & $11.2 \pm 3.7 \mathrm{c}$ & $25.4 \pm 6.1^{\mathrm{c}}$ & $12.2 \pm 1.6^{\mathrm{c}}$ & $26.9 \pm 8.3^{c}$ & $14.9 \pm 5.1^{\mathrm{c}}$ \\
\hline $\mathrm{T} 17$ & $82.5 \pm 27.1^{\mathrm{a}}$ & $46.5 \pm 11.9^{a}$ & $78.9 \pm 23.6^{\mathrm{a}}$ & $50.9 \pm 13.2^{\mathrm{a}}$ & $72.3 \pm 20.6^{a}$ & $55.3 \pm 22.4^{\mathrm{a}}$ & $78.5 \pm 24.8^{\mathrm{a}}$ & $49.1 \pm 15.2^{\mathrm{a}}$ \\
\hline $\mathrm{T} 18$ & $20.1 \pm 4.2^{\mathrm{cd}}$ & $12.8 \pm 6.3^{c}$ & $25.8 \pm 17.1^{\mathrm{c}}$ & $12.4 \pm 3.6^{\mathrm{c}}$ & $22.7 \pm 5.4^{\mathrm{c}}$ & $14.1 \pm 3.9^{c}$ & $25.3 \pm 4.7^{c}$ & $13.3 \pm 4.7^{\mathrm{c}}$ \\
\hline T19 & $14.6 \pm 3.7^{\mathrm{d}}$ & $6.7 \pm 5.2^{\mathrm{cd}}$ & $12.1 \pm 3.4^{\mathrm{d}}$ & $5.1 \pm 1.7^{\mathrm{cd}}$ & $24.8 \pm 7.3^{\mathrm{c}}$ & $15.3 \pm 6.1^{\mathrm{c}}$ & $14.8 \pm 3.2^{\mathrm{cd}}$ & $13.1 \pm 2.8^{\mathrm{c}}$ \\
\hline $\mathrm{T} 20$ & $28.9 \pm 7.2^{\mathrm{c}}$ & $14.5 \pm 8.2^{c}$ & $16.9 \pm 6.1^{\mathrm{cd}}$ & $10.4 \pm 1.9^{c}$ & $13.3 \pm 1.7^{\mathrm{cd}}$ & $11.7 \pm 4.8^{\mathrm{c}}$ & $27.1 \pm 9.3^{c}$ & $16.5 \pm 4.6^{c}$ \\
\hline $\mathrm{T} 21$ & $11.2 \pm 3.6^{\mathrm{d}}$ & $2.3 \pm 1.4^{\mathrm{d}}$ & $9.1 \pm 3.8^{\mathrm{d}}$ & $2.1 \pm 0.7^{\mathrm{d}}$ & $6.5 \pm 0.8^{\mathrm{d}}$ & $4.6 \pm 1.3^{\mathrm{d}}$ & $8.2 \pm 2.3^{\mathrm{d}}$ & $5.2 \pm 2.4^{\mathrm{d}}$ \\
\hline $\mathrm{T} 22$ & $82.8 \pm 14.5^{\mathrm{a}}$ & $49.8 \pm 13.5^{\mathrm{a}}$ & $81.4 \pm 13.6^{\mathrm{a}}$ & $54.3 \pm 14.9^{\mathrm{a}}$ & $71.6 \pm 18.5^{\mathrm{a}}$ & $54.5 \pm 11.3^{\mathrm{a}}$ & $79.2 \pm 22.4^{\mathrm{a}}$ & $52.9 \pm 12.6^{\mathrm{a}}$ \\
\hline $\mathrm{T} 23$ & $79.6 \pm 11.9^{a}$ & $52.1 \pm 12.4^{\mathrm{a}}$ & $80.1 \pm 16.7^{a}$ & $50.8 \pm 16.5^{\mathrm{a}}$ & $70.8 \pm 20.1^{\mathrm{a}}$ & $58.3 \pm 19.7^{a}$ & $78.2 \pm 17.5^{\mathrm{a}}$ & $50.1 \pm 13.8^{\mathrm{a}}$ \\
\hline $\mathrm{T} 24$ & $84.1 \pm 21.5^{\mathrm{a}}$ & $50.4 \pm 9.8^{\mathrm{a}}$ & $79.8 \pm 12.4^{\mathrm{a}}$ & $54.3 \pm 17.1^{\mathrm{a}}$ & $75.6 \pm 22.5^{\mathrm{a}}$ & $59.8 \pm 19.6^{\mathrm{a}}$ & $81.9 \pm 22.3^{\mathrm{a}}$ & $51.7 \pm 11.4^{\mathrm{a}}$ \\
\hline
\end{tabular}

* Values in the table indicate means \pm standard error. There were three replications for each treatment. The values having a common letter do not significantly differ $(P<0.05)$. T1-T4: the crude extracts of cinnamon, ginger, rosemary and neem dissolved in sterile distilled water (SDW) at concentration $2 \mathrm{~g} / 1$, T5-T10: essential oils of six medicinal plants including coriander, lavender, geranium, thyme, savory and eucalyptus at concentration $20 \mu \mathrm{lEO} / \mathrm{ml} \mathrm{SDW,} \mathrm{T11-T14:} \mathrm{the} \mathrm{crude} \mathrm{extracts} \mathrm{of} \mathrm{cinnamon,} \mathrm{ginger,}$ rosemary and neem dissolved in sterile distilled water (SDW) at concentration $5 \mathrm{~g} / \mathrm{l}$, T15-T20: essential oils of six medicinal plants including coriander, lavender, geranium, thyme, savory and eucalyptus at concentration $50 \mu \mathrm{EO} / \mathrm{ml} \mathrm{SDW}$, T21: fungicide iprodione (Rovral WP, $50 \%$ a.i.; maximum advised application rate $500 \mathrm{~g} \mathrm{ha}^{-1}$ ) sprayed at $100 \%$ the advised rate, T22: SDW, T23: ethanol, T24: no treatment.
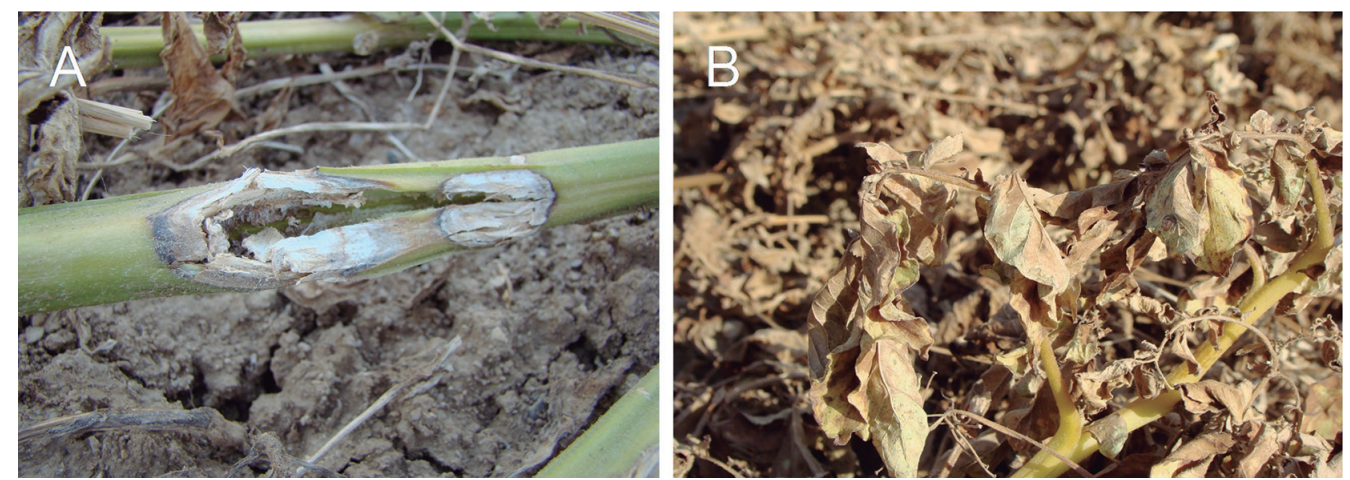

Figure 1. Symptoms of potato stem rot caused by Sclerotinia sclerotiorum. The infection of lower parts of the plants can cause just a bleach (Figure $1 \mathrm{~A}$ ), or this infection can develop to die the whole plants (Figure $1 \mathrm{~B}$ ). 
the naturally infested soils which means there were sclerotia in the soil. However because the number of sclerotia might be different in plots, the number of infected and dead plants were not analyzed. Instead, the percentage of infected and dead plants was presented in Table 1 .

The aromatic plants are able to penetrate and disrupt the fungal cell wall and cytoplasmic membranes, permeablise them and finally damage mitochondrial membranes. The changes in electron flow through the electron transport system inside the mitochondria damage the lipids, proteins and nucleic acid contents (Arnal-Schnebelen et al., 2004). The essential oils can also affect the depolarization of the mitochondrial membranes and decrease the membrane potential and other ion channels. They can also reduce the $\mathrm{pH}$ and affect the proton pump and ATP pool. The change of fluidity in membranes causes the leakage of radicals, cytochrome $\mathrm{C}$, calcium ions and proteins. Thus, permeabilization of outer and inner mitochondrial membranes leads to cell death by apoptosis and necrosis (Yoon et al., 2000).

In this study, the inhibitory effects of treatments against the disease were dissimilar in terms of location and experiment time. It may be because of difference in environmental situations which are various in different locations and over time. The carpogenic germination of sclerotia leading to ascospores production occurs under favorite moisture and temperature. A small change in environmental condition can result in change of ascospore numbers and infection of flowers.

In order to achieve higher control of potato stem rot, it is suggested that spraying extracts or essential oils of medicinal plants are carried out after early detection of $S$. sclerotiorum in potato fields (Ojaghian et al., 2016). Although effectiveness of medicinal plants have been studied against S. sclerotiorum (Badea and Delian, 2014; Ojaghian et al., 2014), this is the first study about inhibitory effect of crude extracts and essential oils of aromatic plants against potato white mold under field condition.

\section{Acknowledgement}

This research was funded by Ton Duc Thang University, Ho Chi Minh City, Vietnam.

\section{Literature Cited}

Adams, P.B.; Ayers, W.A.

1979. Ecology of Sclerotinia species. Phytopathology, 69: 896-898.

Arnal-Schnebelen, B.; Hadji-Minaglou, F.; Peroteau, J.F.; Ribeyre, F.; de Billerbeck, V.G.

2004. Essential oils in infectious gynaecological disease: a statistical study of 658 cases. International Journal of Aromatherapy, 14: 192-197.

Atallah, Z.K.; Johnson, D.A.

2004. Development of Sclerotinia stem rot in potato fields in south-central Washington. Plant Disease, 88: 419-423.

Badea, M.L.; Delian, E.

2014. In vitro antifungal activity of the essential oils from Artemisia spp. L. on Sclerotinia sclerotiorum. Romanian Biotechnological Letters, 19(3): 9345-9352.

Castillo, F.; Hernández, D.; Gallegos, G.; Méndez, M.; Rodríguez, R.; Reyes, A.; Aguilar, C.N.

2010. In vitro antifungal activity of plant extracts obtained with alternative organic solvents against Rhizoctonia solani Kühn. Industrial Crop Production, 32: 324-328.

Gomez, K.A.; Gomez, A.A.

1984. Statistical Procedures for Agricultural Research, John Wiley and Sons, Singapore. 680 pp.

Jo, Y-K.; Niver, A.L.; Rimelspach, J.W.; Boehm, M.J.

2006. Fungicide sensitivity of Sclerotinia homoeocarpa from golf courses in Ohio. Plant Disease, 90: 807-813.
Johnson, D.A.; Atallah, Z.K.

2006. Timing fungicide applications for managing Sclerotinia stem rot of potato. Plant Disease, 90: 755-758.

Ojaghian, M.R.

2010. Biocontrol of potato white mold using Coniothyrium minitans and resistance of potato cultivars to Sclerotinia sclerotiorum. Plant Pathology Journal, 26: 346-352.

Ojaghian, M.R.

2011. Potential of Trichoderma spp. and Talaromyces flavus for biological control of potato stem rot caused by Sclerotinia sclerotiorum. Phytoparasitica, 39: 185-193.

Ojaghian, M.R.; Chen, Y.; Chen, S.; Cui, Z-Q.; Xie, G-L.; Zhang, J-Z.

2014. Antifungal and enzymatic evaluation of plant crude extracts derived from cinnamon and rosemary against Sclerotinia carrot rot. Annals of Applied Biology, 164: 415-429.

Ojaghian, M.R.; Cui, Z-q.; Xie, G-L.; Li, B.; Zhang, J-Z. 2012. Brassica green manure rotation crops reduce potato stem rot caused by Sclerotinia sclerotium. Australasian Plant pathology, 41: 347-349.

Ojaghian, M.R.; Sun, X.; Zhang, L.; Li, X.; Xie, G-L.; Zhang, J.; Wang, L.

2015. Effect of E-cinnamaldehyde against Sclerotinia sclerotiorum on potato and induction of glutathione 
S-transferase genes. Physiological and Molecular Plant Pathology, 91: 66-71.

Ojaghian, M.R.; Wang, L.; Xie, G-L.; Zhang, J-Z.

2019. Inhibitory efficacy of different essential oils against storage carrot rot with antifungal and resistance inducing potential. Journal of Phytopathology, 167: 490-500.

Ojaghian, M.R.; Zhang, J-Z.; Zhang, F.; Qiu, W.; Li, X-L.; Xie, G-L.; Zhu, S-J.

2016. Early detection of white mold caused by Sclerotinia sclerotiorum in potato fields using real-time PCR. Mycologica Progress, 15: 959-965.

Purdy LH.

1979. Sclerotinia sclerotiorum: history, diseases and symptomatology, host range, geographic distribution, and impact. Phytopathol, 69: 875-880.
Yoon, H.S.; Moon, S.C.; Kim, N.D.; Park, B.S.; Jeong, M.H.; Yoo, Y.H.

2000. Genistein induces apoptosis of RPE-J cells by opening mitochondrial PTP. Biochemical and Biophysical Research Communications, 276(1): 151-156.

Zhang, X.L.; Sun, X.M.; Zhang, G.F.

2003. Preliminary report on the monitoring of the resistance of Sclerotinia libertinia to carbendazim and its internal management. Chinese Journal of Pesticide Science Administration, 24: 18-22. 